\title{
Calcitonin
}

\section{A review of experimental and clinical investigations}

\author{
G. V. Foster \\ M.D., Ph.D. \\ Established Investigator of the American Heart Association, Honorary lecturer in Chemical Pathology, \\ Wellcome Unit of Endocrinology, Royal Postgraduate Medical School and Hammersmith Hospital, \\ Ducane Road, London, W.12
}

\section{Summary}

In 1962 Copp proposed the existence of a hypocalcaemic hormone. Subsequent studies have shown him to be right.

Calcitonin is a potent inhibitor of bone resorption. By its action it lowers systemic blood calcium. It is secreted in response to hypercalcaemia by a distinct endocrine system within the thyroid in mammals and within the ultimobranchial bodies in fish, amphibia and reptiles. The active principle from pig has now been isolated and found to be a polypeptide composed of thirty-two amino acid residues. Together with parathyroid hormone, the hormone provides precise regulation of calcium concentration in the blood and controls bone remodelling and mineral turnover. Calcitonin in man may be secreted in excessive amounts by medullary carcinoma of the thyroid. In addition, aberrations in its secretion may play a role in pseudohyperparathyroidism and ostepetrosis.

\section{Introduction}

Calcitonin is a blood-calcium-lowering hormone. In mammals it is secreted by the thyroid in response to hypercalcaemic stimulation (Foster et al., 1964a). The active principle is now recognized to be identical both to the hormone originally attributed to the parathyroids by Copp and his associates (Copp et al., 1962 ; Copp \& Henze, 1964) and to thyrocalcitonin, the hypocalcaemic constituent of rat thyroid described by Hirsch, Gauthier \& Munson (1963). It acts on bone by inhibiting mineral resorption thereby reducing blood calcium. Clinically the hormone is of interest since it is of use in the treatment of hypercalcaemia ; it may prove helpful in the management of osteoporosis (Foster et al., 1968b).

\section{A new endocrine system}

The cells which secrete calcitonin are of ento- dermal origin. Embryologically they derive from the ventral portions of the last pharyngeal pouches (Pearse \& Carvalheira, 1967). In fish, amphibians, reptiles and birds these cells are found in the ultimobranchial bodies, organs of hitherto unknown function.

Hypocalcaemic extracts have been prepared from the ultimobranchial bodies of fish, lizard, turtle, pigeon and chicken (Copp, Cockcroft \& Kueh, 1967 ; MacIntyre, 1967 ; Tauber, 1967 ; Moseley et al., 1968; Parkes \& Copp, 1968). These structures contain as much if not more hormone than the thyroid (Table 1). In mammals they fuse with the thyroid and become incorporated within the gland before birth. Here they constitute an endocrine system distinct from the follicular cells secreting thyroxine and triiodothyronine.

\section{TABLE 1}

Calcitonin content of the thyroid and the ultimobranchial body

\begin{tabular}{|c|c|c|}
\hline & $\begin{array}{l}\text { Ultimobranchial body } \\
\text { (MRC milli-units/mg) }\end{array}$ & $\begin{array}{c}\text { Thyroid } \\
\text { (MRC } \text { milli-units/mg) }\end{array}$ \\
\hline Pig & - & 10.0 \\
\hline Chicken & 37.8 & 0.9 \\
\hline Pigeon & 3.5 & $3 \cdot 4$ \\
\hline Lizard & $3 \cdot 6$ & 1.0 \\
\hline
\end{tabular}

In view of the multi-organ distribution of the secreting cells, the name 'calcitonin' for the hormone is to be preferred. Adoption of this terminology does not detract from the contributions of other investigators who have used the alternative term, 'thyrocalcitonin'.

\section{Secretion}

\section{Stimulus}

In 1962 Copp and his associates demonstrated 
that falls in blood calcium occur when the thyroid, together with the parathyroid glands, is perfused with hypercalcaemic blood (Copp et al., 1962). This finding, first observed in dogs, has been confirmed (Kumar, Foster \& McIntyre, 1963 ; Bernstein, Kleeman \& Pine, 1965) and shown to be due to stimulation of the thyroid (Foster et al., 1965 ; Care, Duncan \& Webster, 1967). Isolated perfusion of the parathyroid in the goat (Foster et al., 1964a) and the rat (Dale, Roth \& Garcia, 1965) have excluded the latter gland as an additional source of the hormone.

Experimental evidence suggests the hormone is secreted under normocalcaemic conditions (Talmage, Neuenschwander \& Kraintz, 1965 ; Minkin \& Talmage, 1968). The secretion rate, however, is greatly increased by hypercalcaemia and may, in some animals, approach one-quarter the total hormonal content of the thyroid gland over a 4-hr period (Care et al., 1968).

\section{Interrelation with other endocrine organs}

No conclusive evidence exists for extrathyroidal regulation of calcitonin secretion. Nonetheless, various reports have implicated the parathyroid and the pituitary.

\section{Parathyroids}

To reconcile early claims for a thyroid and parathyroid origin of the hormone, Gittes \& Irvin (1965) proposed a parathyroid releasing factor. It was suggested this substance stimulated thyroid secretion of calcitonin. Cumulative evidence, however, has failed to support this thesis. (Baghdiantz et al., 1965 ; Foster, 1966 ; Gittes, Wells \& Irvin, 1967).

\section{Pituitary}

The number of calcitonin-secreting cells increases following hypophysectomy (Thompson, Isler \& Sarkar, 1962; Kracht et al., 1968). The findings are consistent with pituitary control of calcitonin secretion. The results, however, may also be interpreted as a decrease in the number of follicular cells. Failure to detect a difference in the amounts of extractable calcium-lowering activity from the thyroids of hypophysectomized and intact rats is presumptive evidence that calcitonin secretion is not under pituitary control (Baghdiantz et al., 1965 ; Milhaud \& Moukhtar, 1965).

\section{The $\mathbf{C}$ cells}

The calcitonin-secreting cells were first identified by Pearse and his colleagues (Foster, MacIntyre \& Pearse, 1964b ; Pearse, 1965), who observed that the levels of certain enzymes in the parafollicular cells of the dog thyroid were sen- sitive to changes in calcium concentration. Immunofluorescent studies have confirmed their conclusions (Bussolati \& Pearse, 1967; Kracht et al., 1968). In earlier literature these cells have been referred to as light cells, mitochondrionrich cells, ovoid cells, interfollicular cells, parenchymatous cells and protoplasm-rich cells. As none of these terms describes a general cell-type, they have been renamed ' $C$ cells' to identify them with calcitonin (Pearse, 1966a) Their histological and cytochemical characteristics are as follows:

(1) Preferential staining with Mallory's aniline blue and Cajal's silver nitrate (Pearse, 1966a).

(2) Relatively high content of $\alpha$-glycerophosphate dehydrogenase, esterase (Fig. 1) and cholinesterase (Foster, MacIntyre \& Pearse, 1964b; Pearse, 1966a ; Carvalheira \& Pearse, 1967).

(3) high concentration of ribonucleic acid (Carvalheira \& Pearse, 1967).

(4) Ability to concentrate 5-hydroxytryphan and DOPA in vivo (Pearse, 1966b; Owman \& Sundler, 1968).

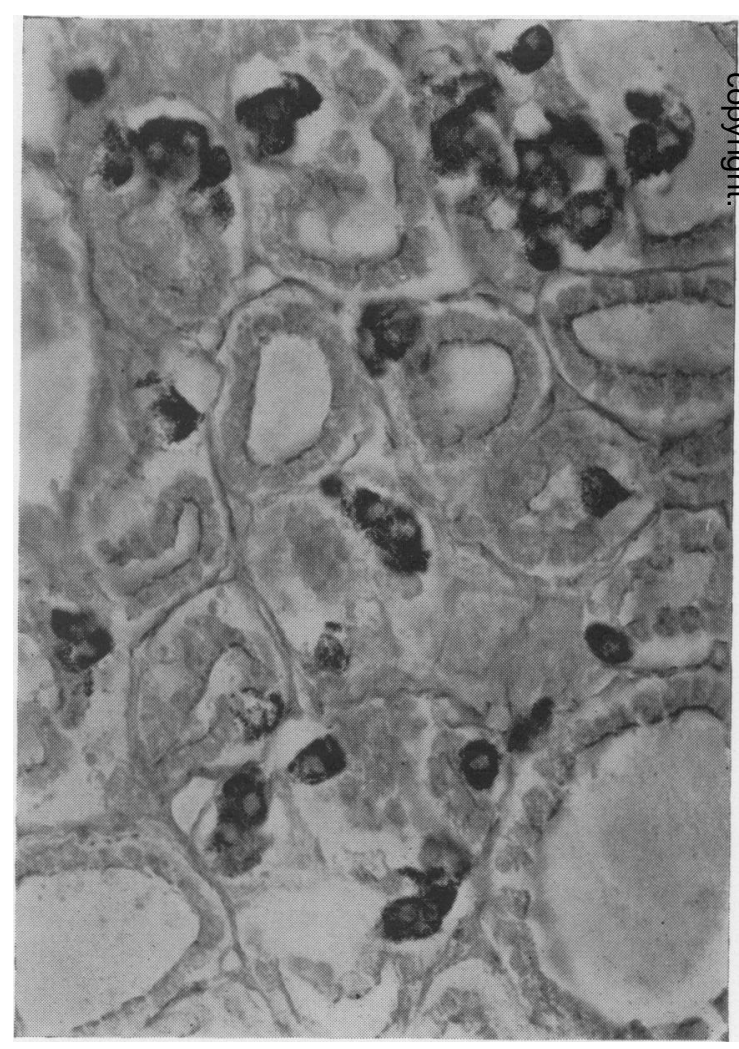

FIG. 1. C cells in the guinea-pig thyroid stained by the Cajal silver nitrate method, $\times 370$. (Courtesy of Professor A. G. E. Pearse, unpublished.) 
(5) Toluidine blue metachromasia (Solcia \& Sampietro, 1968).

(6) Inability to concentrate iodine (Azzali, 1968).

Despite variations in morphology these distinctive features are shared by widely different species.

The $\mathrm{C}$ cells are located near the basement membrane of the thyroid follicle but not in contact with the colloid. In contrast with follicular cells, they are larger and have clear cytoplasm. In the dog they are found in association with capillaries into which they presumably secrete. Their ultrastructure consists of small electron-dense mitochondria, a high level of free ribosomes and numerous spherical vesicles bounded by a single membrane (Pearse, 1966a). The latter contain electron-dense material sometimes in the form of discrete granules. Similar granules with calcitonin-like activity occur in thyroid-gland homogenates (Bauer \& Teitelbaum, 1966 ; Cooper \& Tashjian, 1966). These particles probably are the secretory products and have been shown to be released by hypercalcaemic stimulation (Matsuzawa \& Kurosumi, 1967 ; Cameron, 1968).

Changes suggestive of increased cellular activity are also observed in the ultimobranchial body of frogs made hypercalcaemic (Robertson, $1968 \mathrm{a}, \mathrm{b})$. The induced hypertrophy and hyperplasia of the epithelial cells are consistent with an ultimobranchial source of the hormone in amphibia.

\section{Assay}

Purification of calcitonin has depended upon a reliable assay. Of the various methods employed, all have depended on the measurement of falls in blood calcium produced in the rat (Hirsch, Voelkel \& Munson, 1964 ; Kumar et al., 1965). Within limits this fall is related linearly to the logarithm of the dose given. Recent modifications of the basic assay to improve sensitivity have included the use of very young rats (Milhaud, Pérault-Staub \& Moukhtar, 1965b ; Sturtridge \& Kumar, 1968), appropriate diets (Copp \& Kuczerpa, 1968) and more sensitive animal strains (Cooper et al., 1967).

Different laboratories are now able to express their results in terms of a single unit. The Medical Research Council have made internationally available a biological standard known as 'Research Standard B for Thyroid Calcitonin'. The unit is defined as the calcium-lowering activity contained in one ampoule. This unit is equivalent to approximately 1000 'Hammersmith Units' (Baghdiantz et al., 1964) or 100 'Hirsch
Units' (Hirsch et al., 1964). Ten MRC milli-units will lower the blood calcium roughly $10 \%$ in a starved 150-g rat bled $1 \mathrm{hr}$ after intravenous injection. (Requests for Research Standard B should be sent to the Division of Biological Standards, National Institute for Medical Research, Mill Hill, London, N.W.7, attention of Dr J. A. Parsons.)

Biological estimation of potency can be made providing precautions are taken to prevent surface adsorption of the hormone (Parsons \& Woodward, 1968). Preparations of high specific activity readily lose potency in this way, while crude preparations do not. The loss can be prevented by addition of protein to solutions used to dissolve and dilute the hormone (Parsons, 1968).

\section{Purification}

Porcine calcitonin has been isolated independently by several research teams (Putter et al., 1967 ; Hawker, Rasmussen \& Glass, 1967 ; MacIntyre, 1967; Gudmundsson et al., 1968; Potts, 1967 ; Kahnt et al., 1968 ; Franz et al., 1968 ; Bell, 1968). Purification requires a combination of techniques including solvent extraction, precipitation, gel filtration, partition chromatography, countercurrent distribution and preparative gel electrophoresis. Three or four separate active fractions are found (Gudmundsson et al., 1968; Putter et al., 1967 ; Neher \& Kahnt, 1968 ; Bell, 1968). The amino acid composition of the major component has now been characterized (Table 2).

TABle 2

Amino acid composition of porcine calcitonin

\begin{tabular}{lc}
\hline \multicolumn{1}{c}{ Amino acid } & Residues \\
\hline Aspartic acid & 4 \\
Threonine & 2 \\
Serine & 4 \\
Glutamic acid & 1 \\
Proline & 2 \\
Glycine & 3 \\
Alanine & 1 \\
Valine & 1 \\
1-Cystine & 2 \\
Methionine & 1 \\
Isoleucine & 0 \\
Leucine & 3 \\
Thyrosine & 1 \\
Phenylalanine & 3 \\
Lysine & 0 \\
Histidine & 1 \\
Arginine & 2 \\
Tryptophan & 1 \\
Total & 32 \\
\hline
\end{tabular}

Putter et al. (1967), MacIntyre (1967) and Kahnt et al. (1968). 
The hormone is a polypeptide (Baghdiantz et al., 1964 ; Hirsch et al., 1964). The major active fraction is composed of thirty-two amino acid residues suggesting a molecular weight of 3600 . This figure is in essential agreement with previous estimates (MacIntyre, Foster \& Kumar, 1965 ; O'Riordan et al., 1966 ; Potts et al., 1967). Its composition is distinguished by: (1) the absence of isoleucine and lysine, (2) no free terminal amino group, and (3) the presence of five of six potential carboxyl groups as amides (Putter et al., 1967).

\section{Action on bone}

The hormone acts by inhibiting calcium resorption. Whether it affects bone formation remains uncertain.

A number of techniques have been used to study the effect on bone. Since the possible clinical usefulness of the hormone is dependent upon these basic observations, each deserves brief comment.

\section{Culture studies}

The hormone prevents the release of calcium from cultured embryonic bone in vitro. Resorption of calcium-45 in pre-labelled bone is inhibited by calcitonin (Friedman \& Raisz, 1965). Likewise, gross loss of mineral is prevented by the hormone (Aliapoulios, Goldhaber \& Munson, 1966a). Inhibition is most apparent when resorption is stimulated by either parathyroid hormone (Friedman \& Raisz, 1965 ; Aliapoulios et al., 1966a) or vitamin A (Aliapoulios, 1966a ; Reynolds, 1968 ; Reynolds et al., 1968).

Calcitonin does not appreciably affect resorption of bone-matrix hydroxyproline in acute studies (Raisz et al., 1968). Neither does it increase the uptake of labelled proline, a precursor of collagen, into cultured bone (Goldhaber et al., 1968). This latter finding suggests that the hormone does not increase bone formation rate. Changes in the relative distribution of bone cells, however, indicate that the reverse should be true. Calcitonin decreases the number of osteoclasts and increases the number of osteoblasts (Gaillard, 1967). The former supports an inhibitory effect on resorption; the latter is consistent with promotion of bone formation.

\section{Kinetic studies}

Calcitonin prevents the release of radioisotopes of calcium and strontium from prelabelled rat bone in vivo (Johnston \& Deiss, 1966; Robinson et al., 1967 ; Wallach et al., 1967 ; Hirsch, 1967). The results accord well with the earlier conclusions of Milhaud, et al. (1965) who related hormone-induced changes in cal- cium-45 specific activity in the rat to a hypothetical four-compartment model.

\section{Bone perfusion studies}

By measuring arterio-venous differences in the isolated cat's tibia, MacIntyre, Parsons \& Robinson (1967) demonstrated that calcitonin increases net calcium retention. While this method has not clarified the mode of action of the hormone, it confirms that the effect observed on the isolated bone can account for the systemic hypocalcaemia produced by the hormone.

\section{Urinary hydroxyproline studies}

Martin, Robinson \& MacIntyre (1966) have observed that the urinary excretion of hydroxyproline is markedly reduced in the rat by prolonged calcitonin infusion. Likewise, hydroxyprolinuria induced by parathyroid hormone is inhibited by the hormone (Pechet et al., 1967 ; Rasmussen \& Tenenhouse, 1967). Since approximately half the hydroxyproline in the body is present in bone, its appearance in urine is a useful index of bone resorption. Diminished excretion is presumptive evidence of inhibition of bone breakdown.

\section{Effects of chronic calcitonin treatment}

In vivo changes produced by calcitonin are most marked in the metabolically active areas? of bone. Foster et al. (1966a) have demonstrated that the hormone increases bone mineral in the metaphyseal areas of caudal vertebrae of parathyroidectomized rats (Fig. 2). In bones of treated animals the relative number of osteoclasts is decreased and the number of osteoblasts increased (Matrajt et al., 1968). These findings are in agreement with the 'cellular shift' observed by Gaillard (1967) in bone-culture studies and are consistent with a possible increase in bone formation rate induced by the hormone. In addition, Foster and his associates (Foster et al., 1967; Matrajt et al., 1968) have found that not only is total metaphyseal bone increased in calcitonin-treated animals, but that the relative percentage of osteoid, the precursor of mineralized bone, is also increased. This observation likewise suggests the hormone may promote new bone formation.

\section{Calcitonin-deficiency studies}

Kumar and his colleagues (1968) have demonstrated changes in bone in chronically thyroidectomized rats adequately maintained on replacement thyroxine. They conclude that bone formation surfaces are reduced in the periosteal and endosteal regions of the femur in the absence of endogenous calcitonin secretion. 
Unquestionably calcitonin inhibits bone mineral resorption. Further investigations are required to assess definitively the role of the hormone on bone formation rate.

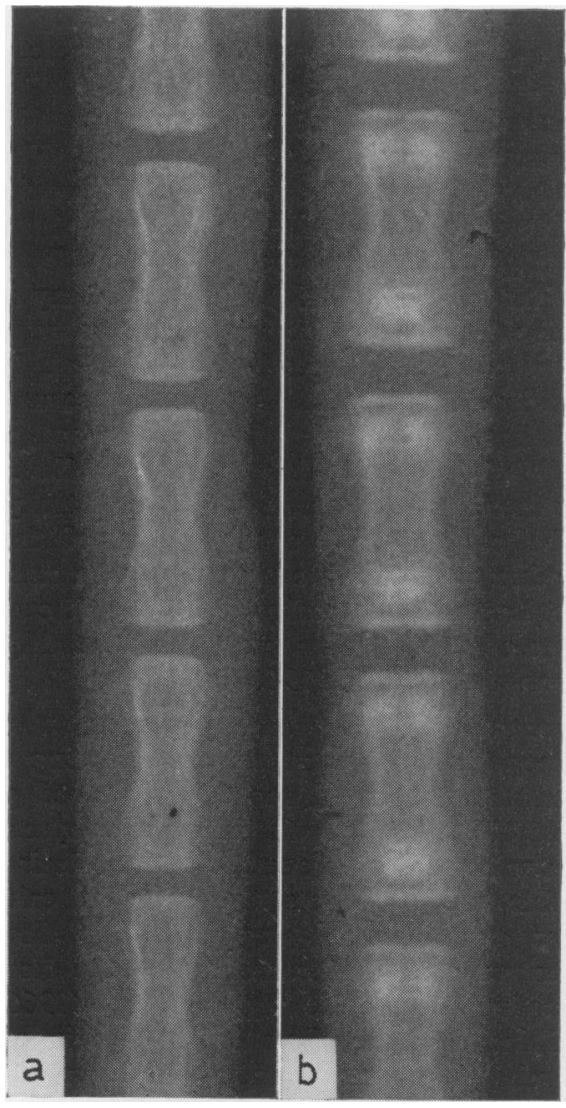

FIG. 2. Longitudinal sections of the 9th to 11 th caudal vertebra of a control rat (a) and a calcitonin-treated animal (b). Trabecular bone central to the growth cartilages in the treated animal is markedly increased relative to the control (Foster et al., 1967).

\section{Action on kidney}

Calcitonin Increases the urinary excretion of phosphate when given in doses in excess of those required to lower blood calcium. The definitive observation was made in rats by Robinson, Martin \& MacIntyre (1966), who drew attention to the need that such studies be carried out in parathyroidectomized animals. In intact animals the calcitonin-induced hypocalcaemia would otherwise stimulate the secretion of parathyroid hormone, which itself produces phosphaturia. In a re-examination of the problem Russell \& Fleisch (1968) perfused the renal artery of dogs and pigs. Their results confirm that phosphaturia is only produced by relatively large doses of the hormone.

The phosphaturic role of calcitonin raises the question of the interpretation of phosphate excretion tests in man. The studies of Robinson et al. (1967) suggest that of the two sites of action, the action on the skeleton usually predominates. By inhibiting bone resorption, plasma calcium and phosphate are lowered even in the absence of the kidneys (Hirsch et al., 1964 ; Gudmundsson, MacIntyre \& Soliman, 1966). Only when the rate of bone resorption is low, as for example following parathyroidectomy, is the phosphaturic action dominant. This may well be true. In intact animals, however, calcitonininduced phosphaturia is increased in conditions of rapid bone turnover (Milhaud, Tsien-Ming \& Moukhtar, 1967). Presumably the phosphaturic action of increased parathyroid hormone secretion is responsible for this finding.

In view of the interrelation of the two hormones and their common effect on renal excretion, interpretation of phosphate excretion tests must be made with reservations.

\section{Possible mechanisms of action}

The calcium-lowering effect of calcitonin is secondary to a direct action of the hormone on the skeleton. Possible effects on the gastro-intestinal tract, kidney and soft tissues have been excluded. Calcitonin is active in degutted animals (Aliapoulios, Savery \& Munson, 1965) and does not affect calcium transport in ligated intestinal loops in vivo (Robinson, Matthews \& MacIntyre, 1968). Similarly the hormone is active in nephrectomized animals (Hirsch et al., 1964 ; Gudmundsson et al., 1966) and does not promote calcuria in intact animals (Kenny \& Heiskell, 1965). Failure to demonstrate an increase in calcium in soft tissue following calcitonin administration likewise excludes an intra-cellular accumulation of the ion as a cause of hypocalcaemia (Gudmundsson et al., 1966 ; Kenny \& Heiskell, 1965).

Clearly calcitonin does not act by simple inhibition of parathyroid hormone since it effectively lowers blood calcium in parathyroidectomized animals (Tashjian, 1965; Gudmundsson et al., 1966). Neither does it appear to affect synthesis of messenger RNA as many other hormones do. Actinomycin D, an inhibitor of RNA synthesis, does not impair its hypocalcaemic activity (Tashjian, 1965 ; Gudmundsson et al., 1966). How then does calcitonin act to prevent bone resorption? Two possibilities have been proposed:

(1) Calcitonin may directly affect bone cells, regulating their activity. The studies of both 
Gaillard (1967) and Foster and his associates (Foster et al., 1966a ; Matrajt et al., 1968) indicate that the hormone decreases the number of osteoclasts and increases the number of osteoblasts.

(2) Wells \& Lloyd (1968) suggest that calcitonin may produce hypocalcaemia by activating phosphodiesterase. Activation of phosphodiesterase enhances degradation of cyclic- $3^{\prime} 5^{\prime}$-adenosine monophosphate which may act directly on bone to promote resorption. Theophylline, which inhibits this enzyme, raises blood calcium in parathyroidectomized rats. Similarly, imidazole, which inhibits it, lowers both calcium and phosphate. While no direct evidence has been found, this is an intriguing possibility.

These two alternatives for the action of the hormone need not be mutually exclusive.

\section{Calcitonin in man}

Calcitonin is present in man. That the hormone is involved in pathological conditions has been inferred by: (1) measuring extractable calcium-lowering activity from human thyroid tissue, (2) studying the response to alterations in systemic blood calcium, and (3) investigating disease conditions in animals. Definitive conclusions concerning secretion rates, however, will have to await further development and application of methods of measuring circulating hormone.

The active principle from human thyroid has been extracted (Hirsch et al., 1964 ; Milhaud et al., 1965a ; Aliapoulios, Voelkel \& Munson, 1966b ; Chausmer, Mittleman \& Wallach, 1966 ; Haymovits \& Rosen, 1967). Extracts of normal glands are much less active in the rat than similarly prepared extracts from pig thyroid. This, however, does not necessarily imply that less hormone is present in man. Factors such as assay-animal sensitivity, enzymatic inactivation of the hormone and relative difficulty of extraction may explain the apparent differences in activity.

\section{Hyperparathyroidism}

Tashjian \& Voelkel (1967) have reported that less calcium-lowering activity is extractable from thyroids from patients with hyperparathyroidism than from normal glands. This observation can be accounted for in one of two ways: either continuous hypercalcaemic stimulation of the thyroid may deplete the gland of the hormone or initially excessive secretion of calcitonin might stimulate hypersecretion of the parathyroid hormone and eventually result in autonomous parathyroid function. While extractable activity does not necessarily reflect changes in secretion rate, the results are provocative.

Pseudohypoparathyroidism

This condition was previously considered to be due to failure of bone to respond to parathyroid hormone. The recent studies of Jowsey (1968) suggest this concept is no longer tenable.

An excess of calcitonin could explain the hypocalcaemia found in this condition (Fischer, Binswanger \& Frey-Wettstein, 1967). Thyroids from two patients have contained approximately 100 times as much calcium-lowering activity as normal glands (Aliapoulios et al., 1966b ; Tashjian, Frantz \& Lee, 1966). Thyroidectomy in one patient with the disease resulted in a return of calcium to normal levels (Mazzuoli et al., 1968b). Thyroidectomy is not, however, recommended since alleviation of the disease was not permanent (Mazzuoli, Coen \& Antonozzi, 1968a).

An increase in calcium-lowering activity may also be explained by accumulation of the hormone due to inadequate stimulation. In rats made hypocalcaemic by parathyroidectomy, the thyroid content of calcitonin is greatly increased (Gittes, Munson \& Toverud, 1966).

\section{Osteopetrosis}

Osteopetrosis is a naturally occurring condition in the grey-lethal mouse, an inbred genetic mutant. Affected animals have metaphyseal sclerosis similar to that found in man. Their bones resemble those of rats treated with calcitonin (Foster et al., 1966a), suggesting the disease is due to an excess of secretion of the hormone. Supporting this aetiology, Walker (1966) has found increased numbers of $C$ cells in affected mice relative to their unaffected litter mates.

\section{Thyroid disorders}

There is histological and other evidence that medullary carcinoma of the thyroid is a hypersecreting calcitonin tumour. Greatly increased levels of calcium-lowering activity in both blood and tumour tissue have been demonstrated in two patients (Milhaud et al., 1968 ; Melvin \& Tashjian, 1968).

Excessive secretion of calcitonin may also be associated with certain non-neoplastic conditions (Mazzuoli, Coen \& Baschieri, 1966; Chimènes and Klotz, 1967). Surgical removal of the thyroid in several patients appears to have corrected preexisting hypocalcaemia. Milhaud et al. (1965a), however, have not found appreciable differences in extractable calcitonin activity in goitrous and normal thyroid tissue. Clearly, no conclusions can be drawn at this time.

Thyroidectomy impairs calcium homeostasis (Woodhouse \& Barnes, 1968; Smith \& Laljee, 
1967; Williams et al., 1966). The findings support the thesis that calcitonin is physiologically important in man. Following intravenous calcium, athyroidal patients require longer for their blood calcium levels to return to normal than control patients. Reservations must be made, however, in the interpretation of the results as thyroidectomy can impair parathyroid function and the rate of bone mineral turnover if adequate thyroxine replacement is not given.

\section{Calcitonin in animals}

In 1963 Hirsch, Gauthier \& Munson observed that acid extracts of the rat thyroid produce hypocalcaemia and hypophosphataemia when injected into laboratory animals. Their now classical investigations were stimulated by the finding that cautery of the thyroid during parathyroidectomy lowered serum calcium in the rat. Calciumlowering activity has since been found in the thyroid or ultimobranchial body of fish, lizard, turtle, pigeon, chicken, guinea-pig, rabbit, dog, pig, goat, sheep, deer, ox and monkey (Baghdiantz et al., 1964 ; Foster et al., 1964a ; Hirsch et al., 1964 ; Foster et al., 1965 ; Chausmer et al., 1966; Moseley et al., 1968; Parkes \& Copp, 1968).

The hormone may play a role in three unique conditions in animals: parturient paresis, hibernation and artificially induced soft-tissue calcification.

\section{Parturient paresis}

Parturient paresis is a spontaneous afebrile disease of dairy cows characterized by hypocalcaemic tetany and, in the later stages, paralysis and coma. Unless treated by intravenous calcium solutions the disease is invariably fatal. The investigations of Capen \& Young (1967) suggest that increased calcitonin secretion may be responsible for this condition. Two factors support their conclusion. First, only a quarter as much extractable calcium-lowering activity is found in thyroids of diseased cows as in healthy animals. Second, calcitonin-secreting cells are less obvious in this condition and have the appearance of having discharged their secretory products.

\section{Hibernation}

A relation between calcitonin secretion and hibernation appears to exist. As many physiological functions undergo seasonal changes in hibernating animals, this would not be surprising were it not that hypocalcaemia is present in this condition. Nunez and his associates (1967) have identified cells in the thyroid of the bat similar to the $\mathrm{C}$ cells described by Pearse (1966a). Characteristically they contain secretory granules in their cytoplasm. During the months shortly before the bat hibernates these granules vary greatly in size, some becoming many times larger. With the onset of hibernation the secretory product is released and only empty vesicles remain. Similar findings are observed in the thyroid of another hibernating animal, the bear (Azzali, 1968). In the latter species hypercalcaemia is present prior to hibernation which may account for the release of these secretory granules which are presumed to be calcitonin.

\section{Soft-tissue calcification}

Calcitonin greatly reduces or completely prevents soft tissue calcification induced artificially. Gabbiani and her co-workers (1968) have produced ectopic calcified lesions by four methods: exogenous administration of parathyroid hormone to thyroparathyroidectomized rats, inducing increased endogenous parathyroid hormone activity by nephrectomy in intact animals, cutaneous calcergy stimulated by intravenous lead acetate and subcutaneous polymyxin, and calciphylaxis provoked in dihydrotachysterol-treated animals by challenge with either depilation or subcutaneous injection of ferric dextran. In each study the lesions produced were minimized by pretreatment with calcitonin. As inhibition of mineral resorption cannot account for the findings, the more likely explanation is that calcitonin-induced hypocalcaemia protects against soft-tissue calcification.

\section{Measurement of calcitonin in biological fluids}

The measurement of calcitonin blood-levels is a prerequisite to the study of the role of the hormone in health and disease. Several approaches to the problem are under study.

\section{Bone culture}

Au, Niemann \& Raisz (1967) have measured calcitonin in rat sera by assaying the effects of the hormone on parathyroid-hormone-induced bone resorption in vitro. As endogenously secreted parathyroid hormone interferes, the assay is limited to measuring calcitonin in sera from parathyroidectomized animals. At present the method is relatively insensitive and will not be applicable to the assay of the hormone in man unless interfering serum parathyroid hormone can be removed.

\section{Bioassay}

Sturtridge \& Kumar (1968) are able to detect calcium-lowering activity from extracts of human plasma using an improved bioassay in young rats. The active substance is partially purified by precipitation, solvent extraction and gel filtration. Calcitonin-like activity has been detected in two 
healthy volunteers before and after an intravenous calcium infusion. A two- to three-fold increase in activity was detected following stimulation. If the calcium-lowering activity can be shown to be due to calcitonin, this technique may prove applicable to resolving many of the unanswered questions in man.

\section{Immunoassay}

As yet no suitable radioimmunoassay for calcitonin is available. Arnaud \& Littledyke (1966) have reported the measurement of a peptide in the blood of pigs, the levels of which rise when the animal is stimulated with exogenous calcium and which cannot be detected in the absence of the thyroid. Since their iodinated hormone was later recognized not to be calcitonin, their observation cannot be interpreted.

\section{The physiological importance of the hormone}

Calcitonin has two possible roles: control of calcium blood levels and regulation of bone mineralization. As these functions are closely interrelated, a distinction between the two is difficult. Both are probably operative, their relative importance depending upon the needs of the organism.

Calcium is essential for the normal maintenance of cardiac rhythmicity, nerve conduction, muscular contraction and blood coagulation, as well as many important enzymatic reactions. Endocrine regulation of calcium was previously thought to be mediated through changing rates of secretion of parathyroid hormone. Secretion is known to be stimulated by hypocalcaemia. Hypocalcaemia, in turn, is corrected by parathyroid hormone mobilization of calcium from bone. This negative feed-back system is unquestioned. It now appears a second feed-back system exists (Fig. 3). Calcitonin, secreted by thyroid or ultimobranchial bodies, acts in opposition to parathyroid hormone. Its secretion is stimulated by hypercalcaemia. By inhibiting bone resorption it lowers blood calcium. Acting together, both hormones provide the precise control required to maintain blood calcium within physiological limits appropriate to its functions.

Calcitonin is probably also essential for the control of remodelling processes and the maintenance of adequately mineralized bone. During growth, increased secretion of both calcitonin and parathyroid hormone may account for the more rapid bone turnover. A high rate of secretion of parathyroid hormone could account for the increased gastro-intestinal absorption of calcium; calcitonin would prevent hypercalcaemia and facilitate bone mineralization. Possibly increased calcitonin secretion is associated with 'physiological goitre'. Enlarged thyroids are frequently found during infancy, puberty and pregnancy when the needs of the body for cal cium are greatest. This thesis is in agreement? with the suggestion of Hirsch \& Cooper (1968) that calcitonin may also act to preserve the in-

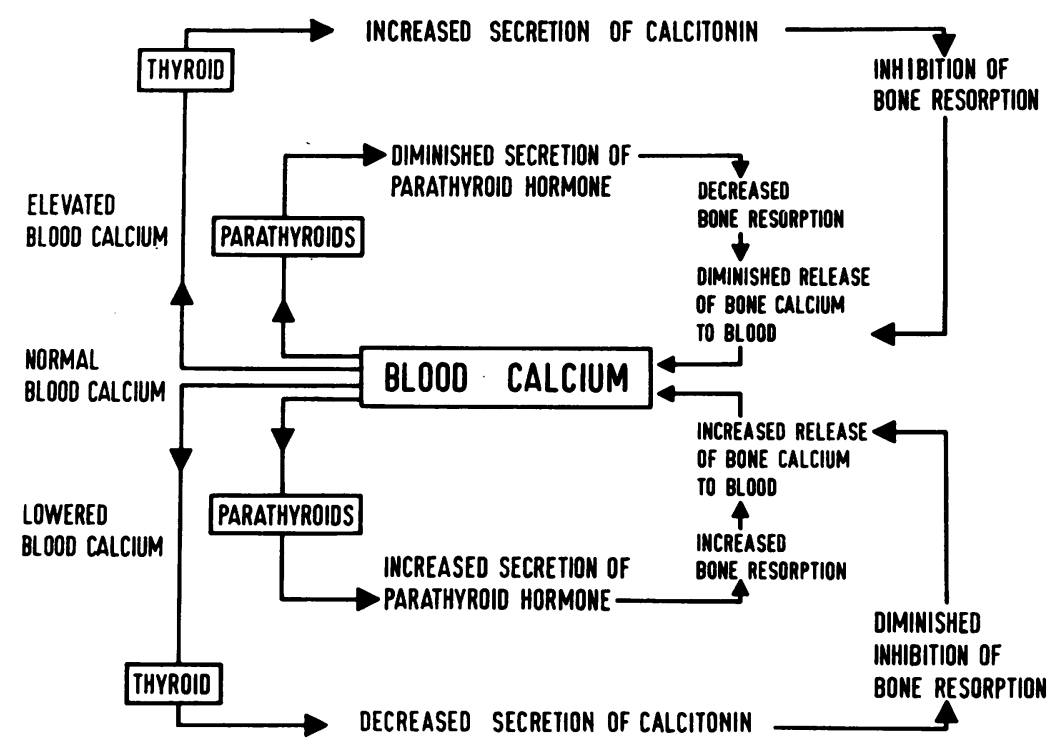

FiG. 3. Diagram of hormonal control of calcium metabolism. 
tegrity of the skeleton during periods of dietary deprivation of calcium when presumably bone would be more sensitive to the effects of the hormone.

\section{Therapeutic uses}

\section{Hypercalcaemia}

Porcine calcitonin is active in man. The hormone reduces the hypercalcaemia of malignancy, hyperparathyroidism, Paget's disease and hypervitaminosis $D$ as well as idiopathic hypercalcaemia (Foster et al., 1966b ; Milhaud et al., 1965a ; Bijvoet \& Jansen, 1967 ; Milhaud, 1968). Doses of less than 1 MRC unit produce falls in blood calcium. The hypocalcaemic effect appears related to the magnitude of the pre-existing hypercalcaemia (Hass \& Dambacher, 1968 ; Foster et al., 1968d). Two explanations are tenable. Either hypercalcaemia suppresses secretion of parathyroid hormone allowing calcitonin to act unopposed or hypercalcaemia is associated with more rapid bone turnover, and therefore, the effect on calcium blood levels of inhibition of bone resorption is more apparent. Both interpretations may be correct. The former concurs with present concepts of parathyroid hormone secretion (Sherwood et al., 1966). The latter is consistent with the greater calcium-lowering effect of calcitonin in conditions favouring increased bone turnover (Milhaud, 1968).

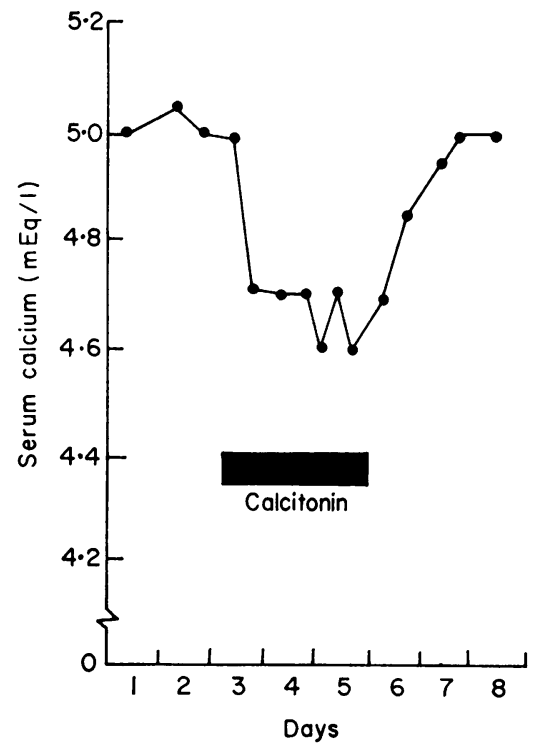

FIG. 4. Changes in serum calcium in an osteoporotie patient treated with $33 \mathrm{MRC}$ units of calcitonin three times a day (Foster et al., 1968.)

\section{Osteoporosis}

Whether the hormone will prove effective in the treatment of osteoporosis in man has yet to be shown. Preliminary studies suggest the hormone acts on the skeleton in this condition (Foster et al., 1968b) and that its effect is sustained (Foster et al., 1968c, Fig. 4). Prolonged clinical trials, however, will be required to determine if a beneficial effect is produced on bone.

\section{Acknowledgment}

This work was done during the tenure of an Established Investigatorship of the American Heart Association.

\section{References}

Aliapoulios, M.A., Goldhaber, P. \& Munson, P.L. (1966a) Thyrocalcitonin inhibition of bone resorption induced by parathyroid hormone in tissue culture. Science, 151, 330.

Aliapoulios, M.A., Savery, A. \& Munson, P.L. (1965) New experiments with thyrocalcitonin. Fed. Proc. 24, 322.

Aliapoulios, M.A., Voelkel, E.F. \& Munson, P.L. (1966b) Assay of human thyroid glands for thyrocalcitonin activity. J. clin. Endocr. 26, 897.

ARNAUD, C. \& LitTledyke, T. (1966) The measurement of thyrocalcitonin in human and pig plasma by radioimmunologic means. J. clin. Invest. 45, 982.

AU, W.Y.W., NiemanN, I. \& RaISz, L.G. (1967) Detection of thyrocalcitonin in the serum of hypercalcemic rats. Fed. Proc. 26, 368.

AzzaLI, G. (1968) Ultrastructure of the para-follicular cells. In: Calcitonin: Symposium on Thyrocalcitonin and the $C$ Cells (Ed. by S. Taylor), p. 152. Heinemann Medical, London.

Baghdiantz, A., Blanquet, P., Croizet, M., Moura, A.M. \& TAYEAU, F. (1965) A propos du facteur hypocalcémiant de la thyroid (calcitonine). C.R. Acad. Sci. (Paris), 261, 2779.

Baghdiantz, A., Foster, G.V., Edwards, A., Kumar, M.A. Slack, E., Soliman, H. \& MacInTYRe, I. (1964) Extraction and purification of calcitonin. Nature (Lond.), 203, 1027.

BaUer, W.C. \& TeItelbaum, S.L. (1966) Thyrocalcitonin activity of particulate fractions of the thyroid gland. Lab. Invest. 15, 323.

Bell, N.H. (1968) Purification and chemical studies of thyrocalcitonin. In: Calcitonin: Symposium on thyrocalcitonin and the C Cells (Ed. by S. Taylor), p. 77. Heinemann Medical, London.

Bernstenn, D., Kleeman, C.R. \& Pine, S. (1965) The effect of thyroparathyroid perfusion with hyper and hypocalcemic blood on calcium, phosphate and magnesium metabolism. Clin. Res. 13, 105.

Bisvoet, O.L.M. \& JANSEN, A.P. (1967) Thyrocalcitonin in Paget's disease. Lancet, ii, 471.

Bussolati, G. \& Pearse, A.G.E. (1967) Immunofluorescent localization of calcitonin in the ' $C$ ' cells of pig and dog thyroid. J. Endocr. 37, 205.

Cameron, D.A. (1968) Osteocytes and osteoclasts in hyperparathyroid and parathyroidectomized rats. Electron microscopic studies. In: Parathyroid Hormone and Thyrocalcitonin (Calcitonin) (Ed. by R. V. Talmage and L.F. Bélanger). Excerpta Medica, Amsterdam. (In press).

CAPEN, C.C. \& Young, D.M. (1967) Thyrocalcitonin: Evidence for release in a spontaneous hypocalcemic disorder. Science, 157, 205. 
Care, A.D., Cooper, C.W., Duncan, T. \& Orimo, H. (1968) The direct measurement of thyrocalcitonin secretion rate in vivo. In: Parathyroid Hormone and Thyrocalcitonin (Calcitonin) (Ed. by R. V. Talmage and L. F. Bélanger). Excerpta Medica, Amsterdam. (In press).

Care, A.D., Duncan, T. \& Webster, D. (1967) Thyrocalcitonin and its role in calcium homeostasis. J. Endocr. 37, 155.

Carvalheira, A.F. \& Pearse, A.G.E. (1967) Comparative cytochemistry of ' $C$ ' cell esterases in the mammalian thyroid-parathyroid complex. Histochemie, 8, 175.

Chausmer, A., Mittleman, R. \& Wallach, S. (1966) Studies of thyrocalcitonin action. Endocrinology, 79, 131.

Chimènes, H. \& Klotz, H.P. (1967) Thyrocalcitonin-excess syndrome. Lancet, $\mathrm{i}, 111$.

CoOPer, C.W., Hirsch, P.F., Toverud, S.U. \& Munson, P.L. (1967) An improved method for the biological assay of thyrocalcitonin. Endocrinology, 81, 610.

CoOPER, C.W. \& TASHJiAN, A.H., JR (1966) Subcellular localization of thyrocalcitonin. Endocrinology, 79, 819.

Copp, D.H., CAMERoN, E.C., Cheney, B.A., Davidson, A.G.F. \& HENZE, K.G. (1962) Evidence for calcitonin-a new hormone from the parathyroid that lowers blood calcium. Endocrinology, 70, 638.

CoPP, D.H., CockcrofT, D.W. \& KueH, Y. (1967) Calcitonin from ultimobranchial glands of dogfish and chickens. Science, 158, 924.

COPP, D.H. \& HENZe, K.G. (1964) Parathyroid origin of calcitonin-evidence from perfusion of sheep glands. Endocrinology, 75, 49.

COPP, D.H. \& KuCzerPA, A.V. (1968) A new bioassay for calcitonin and effect of age and dietary on the response. In: Calcitonin: Symposium on Thyrocalcitonin and the ' $C$ ' Cells (Ed. by S. Taylor), p. 18. Heinemann Medical, London.

Dale, D.C., Roth, S.I. \& Garcia, G.E. (1965) Effect of calcium on parathyroid secretion. Endocrinology, 77, 725.

Fischer, J.A., Binswanger, U. \& Frey-WetTSTeIN, M. (1967) Hypoparathyroidism, hyperostosis, normophosphataemia and thyrocalcitonin. A possible case of hyperthyrocalcitoninism. Acta endocr. (Kbh.), 55, 562.

Foster, G.V. (1966) Thyrocalcitonin: Failure to demonstrate a parathyroid releasing factor. Nature (Lond.), 211, 1319.

Foster, G.V., Baghdiantz, A., Kumar, M.A., Slack, E., Soliman, H.A. \& MACINTYRe, I. (1964a) Thyroid origin of calcitonin. Nature (Lond.), 202, 1303.

Foster, G.V., Clark, M., DOYle, F.H., Joplin, G.F., SINGER, F.R., Fraser, T.R. \& MACINTYRe, I. (1968a) Clinical applications of calcitonin. In: Parathyroid Hormone and Thyrocalcitonin (Calcitonin) (Ed. by R. V. Talmage and L. F. Bélanger). Excerpta Medica, Amsterdam. (In press).

Foster, G.V., Doyle, F.H., Bordier, P. \& Matrajt, H. (1966a) Effect of thyrocalcitonin on bone. Lancet, ii, 1428.

Foster, G.V., Doyle, F.H., Bordier, P., Matrajt, H. \& TUN-CHOT, S. (1967) Roentgenologic and histologic changes in bone produced by thyrocalcitonin. Amer. J. Med. 43, 691.

Foster, G.V., Gudmundsson, T.V., Joplin, G.F., Martin, T.J., Thalassinos, N., Fraser, T.R. \& MacIntyre, I. (1968b) Calcitonin: studies in man. In: Calcitonin: Symposium on Thyrocalcitonin and the ' $C$ ' Cells (Ed. by $\mathrm{S}$. Taylor), p. 379. Heinemann Medical, London.

Foster, G.V., Joplin, G.F., MacIntyre, I., Melvin, K.E.W. \& SLACK, E. (1966b) Effect of thyrocalcitonin in man. Lancet, $\mathrm{i}, 107$

Foster, G.V., Kumar, M.A., Baghdiantz, A., Soliman, H., Slack, E., De Bats, A. \& MacIntyre, I. (1965) Preliminary studies on the origin of calcitonin. Calcified Tissues, Proceedings of the 2nd European Symposium on Calcified Tissues, Liege. Mar/Apr. 1964 (Ed. by L. J. Richelle and M. J. Dallamagne), p. 401. Université de Liège.
Foster, G.V., Macintyre, I. \& Pearse, A.G.E. (1964b) Calcitonin production and the mitochondrion rich cells of the dog thyroid. Nature (Lond.), 203, 1029.

Franz, J., Rosenthaler, J., Zehnder, K., Doepfner, W., Haguenin, R. \& ST GUTtMAN (1968) 25. Isolierung, Aminosäurezusammensetzung und tryptischer Abbau von Thyrocalcitonin aus Schweineschilldrüsen. Helv. Chim. Acta, 51, 1.

Friedman, J. \& RAISZ, L.G. (1965) Thyrocalcitonin: inhibitor of bone resorption in tissue culture. Science, $150,1465$.

Gabbiani, G., Tuchweber, B., Côté, G., Pahk, U.S. \& SELYE, H. (1968) Influence of thyroparathyroid apparatus on experimental soft tissue calcification. In: Parathyroid Hormone and Thyrocalcitonin (Calcitonin) (Ed. by R. V. Talmage and L.F. Bélanger). Excerpta Medica, Amsterdam. (In press).

Gaillard, P.J. (1967) Bone culture studies with thyrocalcitonin. Proc. kon. ned. Akad. Wet. C, 70, 309.

GITTES, R.F. \& IRVIN, G.L. (1965) Thyroid and parathyroid roles in hypercalcemia: evidence for a thyrocalcitoninreleasing factor. Science, 148, 1737.

GitTes, R.F., Munson, P.L. \& Toverud, S.U. (1966) Effect of plasma calcium on the thyrocalcitonin content of rat thyroid glands. Fed. Proc. 25, 496.

GitTes, R.F., Wells, S.A. \& Irvin, G.L. (1967) A new role for the parathyroid glands in calcium homeostasis. J. Urol. 97, 1082.

Goldhaber, P., Stern, B.D., Glimcher, M.J. \& Chao, J. (1968) The effects of parathyroid extract and thyrocalcitonin on bone remodeling in tissue culture. In: Parathyroid Hormone and Thyrocalcitonin (Calcitonin) (Ed. by R. $\mathrm{K}$ Talmage and F. L. Bélanger). Excerpta Medica, AmsteP dam. (In press),

Gudmundsson, T.V., Byfield, P.G.H., Galante, L. MACINTYRE, I. (1968) The purification of calcitonin? In: Calcitonin: Symposium on Thyrocalcitonin and the ' $C$ ' Cells (Ed. by S. Taylor), p. 51. Heinemann Medical, London.

Gudmundsson, T.V., MacIntyre, I. \& Soliman, H.A. (1966) The isolation of thyrocalcitonin and a study of its effects in the rat. Proc. roy. Soc. B, 164, 460.

HAAS, H.G. \& DAmbacher, M. (1968) Thyrocalcitonin effects in man. In: Parathyroid Hormone and Thyrocalcitonin (Calcitonin) (Ed. by R. V. Talmage and L. F. Bélanger). Excerpta Medica, Amsterdam. (In press).

Hawker, C.D., Rasmussen, H. \& Glass, J. (1967) Progress on the isolation of porcine thyrocalcitonin. Amer. J. Med. 43, 656.

Haymovits, A. \& Rosen, J.F. (1967) Human thyrocalcitonin. Endocrinology, 81, 993.

Hirsch, P.F. (1967) Thyrocalcitonin inhibition of bone resorption induced by parathyroid extract in thyroparathyroidectomized rats. Endocrinology, 80, 539.

Hirsch, P.F. \& CoOPER, C.W. (1968) Nutritional factors in relation to thyrocalcitonin. In: Parathyroid Hormone and Thyrocalcitonin (Calcitonin) (Ed. by R. V. Talmage and L. F. Bélanger). Excerpta Medica, Amsterdam. (In press).

Hirsch, P.F., Gauthier, G.F. \& Munson, P.L. (1963) Thyroid hypercalcemic principle and recurrent laryngeal nerve injury as factors affecting the response to parathyroidectomy in rats. Endocrinology, 73, 244.

Hirsch, P.F., Voelkel, E.F. \& Munson, P.L. (1964) Thyrocalcitonin: hypocalcemic hypophosphatemic principle of the thyroid gland. Science, 146, 412.

Johnston, C.C. \& Deiss, W.P., JR (1966) An inhibitory effect of thyrocalcitonin on calcium release in vivo and on bone metabolism in vitro. Endocrinology, 78, 1139. 
Jowsey, J. (1968) Bone in parathyroid disorders in man. In: Parathyroid Hormone and Thyrocalcitonin (Calcitonin) (Ed. by R. V. Talmage and L. F. Bélanger). Excerpta Medica, Amsterdam. (In press).

Kahnt, F.W., Riniker, B., Macintyre, I. \& Neher, R. (1968) Thyrocalcitonin. I. Isolierung und Charakterisierung wirksamer Peptide aus Schweineschilddrüsen. Helv. chim. Acta, 51, 214.

KeNNY, A.D. \& Heiskell, C.A. (1965) Effects of crude thyrocalcitonin on calcium and phosphorus metabolism in rats. Proc. Soc. exp. Biol. (N.Y.), 120, 269.

Kracht, J., Hachmeister, U., Breustedt, H.-J., Bonicke, J. \& LENKE, M. (1968) Histopathological investigation on C-cells. In: Calcitonin: Symposium on Thyrocalcitonin and the C Cells (Ed. by S. Taylor), p. 143. Heinemann Medical, London.

Kumar, M.A., Foster, G.V. \& MacIntyre, I. (1963) Further evidence for calcitonin: a rapid-acting hormone which lowers plasma-calcium. Lancet, ii, 480.

Kumar, M.A., Slack, E., Edwards, A., Soliman, H.A., Baghdiantz, A., Foster, G.V. \& MacInTYre, I. (1965) A biological assay for calcitonin. J. Endocr., 33, 469.

Kumar, M.A., Sturtridge, W.C., Jowsey, J. \& Wase, A.W. (1968) Chronic calcitonin deficiency. In: Calcitonin: Symposium on Thyrocalcitonin and the C Cells (Ed. by S. Taylor), p. 322. Heinemann Medical, London.

MACINTYRe, I. (1967) Calcitonin: A general review. Calc. Tiss. Res. 1, 173.

Macintyre, I., Foster, G.V. \& Kumar, M.A. (1965) The thyroid origin of calcitonin. In: The Parathyroid Glands: Ultrastructure, Secretion and Function (Ed. by P. J. Gaillard, R. V. Talmage and A. M. Budy), p. 389. University of Chicago Press.

MacINTYRe, I., Parsons, J.A. \& Robinson, C.J. (1967) The effect of thyrocalcitonin on blood-bone calcium equilibrium in the perfused tibia of the cat. J. Physiol. (Lond.), 191, 393.

Martin, T.J., Robinson, C.J. \& Macintyre, I. (1966) The mode of action of thyrocalcitonin. Lancet, $\mathbf{i}, 900$.

Matrajt, H., Bordier, Ph., Tun-Chot, S., Hioco, D., Foster, G.V. \& DoYLe, F.H. (1968) Histological bone changes produced by calcitonin. In: Calcitonin: Symposium on Thyrocalcitonin and the C Cells (Ed. by S. Taylor), p. 338. Heinemann Medical, London.

Matsuzawa, T. \& Kurosumi, K. (1967) Morphological changes in the parafollicular cells of the rat thyroid glands after administration of calcium shown by electron microscopy. Nature, (Lond.), 213, 927.

Mazzuoli, G.F., Coen, G. \& Antonozzi, I. (1968a) Longterm observation of the effect of thyroidectomy in patients with elevated thyroid thyrocalcitonin content. In: Calcitonin: Symposium on Thyrocalcitonin and the ' $C$ ' Cells (Ed. by S. Taylor), p. 364. Heinemann Medical, London.

Mazzuoli, G.F., Coen, G., Antonozzi, I. \& Scarda, A. (1968b) Effect of total thyroidectomy on chronic tetany in cases with high thyroid calcium activity. In: Les Tissus Calcifiés (Ed. by G. Milhaud and M. Declume). Lons-leSaunier. (In press).

Mazzuoli, G.F., Coen, G. \& Baschieri, L. (1966) Thyrocalcitonin-excess syndrome. Lancet, ii, 1192.

Melvin, K.E.W. \& Tashian, A.H., JR (1968) The syndrome of excessive thyrocalcitonin produced by medullary carcinoma of the thyroid. Proc. nat. Acad. Sci. (Wash.) (In press).

MilHaUd, G. (1968) Utilization of thyrocalcitonin in man in normal and pathological conditions. In: Parathyroid Hormone and Thyrocalcitonin (Calcitonin) (Ed. by R. V. Talmage and L. F. Bélanger). Excerpta Medica, Amsterdam. (In press).

Milhaud, G. \& MoukhtaR, M.S. (1965) Hypophysectomie et thyrocalcitonine. C.R. Acad. Sci. (Paris), $260,3179$.
Milhaud, G., Moukhtar, M.S., Bourichon, J. \& Perault, A.M. (1965a) Existence et activité de la thyrocalcitonine chez l'homme. C.R. Acad. Sci. (Paris), 261, 4513.

Milhaud, G., Pérault, A.M. \& Moukhtar, M.S. (1965b) Etude du mécanisme de l'action hypocalcémiante de la thyrocalcitonine. C.R. Acad. Sci. (Paris), 261, 813.

Milhaud, G., Perault-Staub, A.-M. \& Moukhtar, M.S. (1967) Thyrocalcitonine: effet de l'âge sur l'hypocalcémie et l'hypophosphatémie. C.R. Acad. Sci. (Paris), Ser. D. 264, 110.

Milhaud, G., Tsien-Ming, L. \& Moukhtar, M.S. (1967) Synergie et antagonisme de la thyroxine, de la parathormone et de la thyrocalcitonine sur la calcemie et la phosphatémie. C.R. Acad. Sci. (Paris). Ser. D, 264, 846.

Milhaud, G., Tubiana, M., Parmentier, C. \& Coutris, G. (1968) Epithélioma de la thyroide sécrétant de la thyrocalcitonine. C. R. Acad. Sci. (Paris), Ser. D 266, 608.

Minkin, C., \& Talmage, R.V. (1968) A study of secretion of thyro-calcitonin in normal rats. In: Parathyroid Hormone and Thyrocalcitonin (Calcitonin) (Ed. by R. V. Talmage and L. F. Bélanger). Excerpta Medica, Amsterdam. (In press).

Moseley, J.M., Matthews, E.W., Breed, R.H., Galante, L., TSE, A. \& MACINTYRE, I. (1968) Ultimobranchial origin of calcitonin. Lancet, i, 108.

NeHER, R. \& KAHNT, F.W. (1968) The purification of thyrocalcitonin. In: Calcitonin: Symposium on Thyrocalcitonin and the C Cells (Ed. by S. Taylor), p. 57. Heinemann Medical, London.

Nunez, E.A., Gould, R.P., Hamilton, D.W., Hayward, J.S. \& HoLT, S.J. (1967) Seasonal changes in the fine structure of the basal granular cells of the bat thyroid. J. Cell Sci. 2, 401.

O'Riordan, J.L.H., Tashian, A.H., Munson, P.L., CondLIFFE, P.G. \& AURBACH, G.D. (1966) Thyrocalcitonin: ultracentrifugation in gradients of sucrose. Science, 154, 885.

Owman, C. \& Sundler, F. (1968). Amine mechanisms in parafollicular cells. In: Calcitonin: Symposium on Thyrocalcitonin and the C Cells (Ed. by S. Taylor), p. 110. Heinemann Medical, London.

PARKes, C.O. \& CoPP, D.H. (1968) Isolation of calcitonin from ultimobranchial glands of chicken and dogfish. In: Parathyroid Hormone and Thyrocalcitonin (Calcitonin) (Ed. by R. V. Talmage and L. F. Bélanger). Excerpta Medica, Amsterdam. (In press).

PARSONS, J.A. (1968) Effects of added protein and of vasoactive drugs on apparent potency of thyrocalcitonin assayed intravenously in the rat. In: Calcitonin: Symposium on Thyrocalcitonin and the C Cells (Ed. by S. Taylor), p. 36. Heinemann Medical, London.

Parsons, J.A. \& Woodward, P.M. (1968) Report on collaborative assay of four preparations of porcine thyrocalcitonin in seven laboratories. In: Calcitonin: Symposium on Thyrocalcitonin and the C Cells (Ed. by S. Taylor), p. 42. Heinemann Medical, London.

Pearse, A.G.E. (1965) The enzyme systems of the mammalian parathyroid with a note on calcitonin production. The Parathyroid Glands: Ultra-structure, Secretion and Function (Ed. by P. J. Gaillard, R. V. Talmage and A. M. Budy), p. 27. University of Chicago Press, Chicago.

Pearse, A.G.E. (1966a) The cytochemistry of the thyroid ' $C$ ' cells and their relationship to calcitonin. Proc. Roy. Soc. B, 164, 478.

Pearse, A.G.E. (1966b) 5-Hydroxytryptophan uptake by dog thyroid ' $C$ ' cells, and its possible significance in polypeptide hormone production. Nature (Lond.), 211, 598.

Pearse, A.G.E. \& Carvalheira, A.F. (1967) Cytochemical evidence for an ultimobranchial origin of rodent thyroid C cells. Nature (Lond.), 214, 929. 
Pechet, M.M., Bobadilla, E., Carroll, E.L. \& Hesse, R.H. (1967) Regulation of bone resorption and formation. Infiuences of thyrocalcitonin, parathyroid hormone, neutral phosphate and Vitamin D. Amer.J. Med. 43, 696.

Potts, J.T., JR, Reisfeld, R.A., Hirsch, P.F., Wasthed, A.B. \& Munson, P.L. (1968) Purification and chemical properties of porcine thyrocalcitonin. In: Calcitonin: Symposium on Thyrocalcitonin and the C Cells (Ed. by S. Taylor), pp. 66-73. Heinemann Medical, London.

Putter, I., Kaczka, E.A., Harman, R.E., Rickes, E.L., Kempf, A.J., Chaiet, L., Rothrock, J.W., Wase, A.W. \& WolF, F.J. (1967) The isolation and properties of thyrocalcitonin. J. Amer. chem. Soc. 89, 5301.

RAISZ, L.C., BRAND, J.S., AU, W.Y.W. \& NiemanN, I. (1968) Interactions of parathyroid hormone and thyrocalcitonin on bone resorption in tissue culture. In: Parathyroid Hormone and Thyrocalcitonin (Calcitonin) (Ed. by R. V. Talmage and L. F. Bélanger). Excerpta Medica, Amsterdam. (In press).

Rasmussen, H. \& Tenenhouse, A. (1967) Thyrocalcitonin, osteoporosis and osteolysis. Amer. J. Med. 43, 711.

REYNOLDS, J.J. (1968) Inhibition by calcitonin of bone resorption induced in vitro by vitamin A. Proc. roy. Soc. B (In press).

ReYNolds, J.J., Dingle, J.T., Gudmundsson, T.V. \& MACINTYRE, I. (1968) Bone resorption in vitro and its inhibition by thyrocalcitonin. In: Calcitonin: Symposium on Thyrocalcitonin and the C Cells (Ed. by S. Taylor). Heinemann Medical, London.

ROBERTSON, D.R. (1968a) The ultimobranchial body in Rana pipiens. IV. Hypercalcemia and glandular hypertrophy. Z. Zellforsch. (In press).

ROBERTSON, D.R. (1968b) The ultimobranchial body in Rana pipiens. VI. Hypercalcemia and secretory activityevidence for the origin of calcitonin. Z. Zellforsch. (In press).

Robinson, C.J., Martin, T.J. \& MacInTYRe, I. (1966) Phosphaturic effect of thyrocalcitonin. Lancet, ii, 83.

Robinson, C.J., Martin, T.J., MatThews, E.W. \& MACINTYRE, I. (1967) Mode of action of thyrocalcitonin. J. Endocr. 39, 71.

Robinson, C.J., Matthews, E.W. \& Macintyre, I. (1968) The effect of parathyroid hormone and thyrocalcitonin on the intestinal absorption of calcium and magnesium. In: Les Tissus Calcifiés (Ed. by $\mathbf{G}$. Milhaud and $\mathbf{M}$. Declume). Lons-le-Saunier. (In press).

Russell, R.G.G. \& Fleisch, H. (1968) The renal effects of thyrocalcitonin. In: Calcitonin: Symposium on Thyrocalcitonin and the ' $C$ ' Cells (Ed. by S. Taylor). Heinemann Medical, London.

Sherwood, L.M., Potts, J.T., JR, Care, A.D., Mayer, G.P. \& AURBACH, G.D. (1966) Evaluation by radioimmunoassay of factors controlling the secretion of parathyroid hormone. Intravenous infusions of calcium and ethylenediamine tetraacetic acid in the cow and goat. Nature (Lond.), 209, 52.
Smith, R.N. \& LALJEe, H.C.K. (1967) Thyrocalcitonin deficiency after treatment of thyroid disorders by surgery or radioiodine. Brit. med. J. iv, 589.

Solcia, E. \& SAmpietro, R. (1968) New methods for staining secretory granules and 5-hydroxytryptamine in the thyroid C cells. In: Calcitonin: Symposium on Thyrocalcitonin and the C Cells (Ed. by S. Taylor). Heinemann Medical, London.

Sturtridge, W.C. \& Kumar, M.A. (1968) Human plasma calcitonin. In: Parathyroid Hormone and Thyrocalcitonin (Calcitonin) (Ed. by R. V. Talmage and L.F. Bélanger). Excerpta Medica, Amsterdam. (In press).

TAlmage, R.V., Neuenschwander, J. \& KRaInTz, L. (1965) Evidence for thyrocalcitonin secretion in the rat. Endocrinology, 76, 103.

TAshjian, A.H., JR (1965) Homeostasis of plasma calcium: effects of actinomycin D parathyroidectomy and thyrocalcitonin. Endocrinology, 77, 375.

Tashian, A.H., JR, Frantz, A.G. \& Lee, J.B. (1966) Pseudohypoparathyroidism: assays of parathyroid hormone and $A$ thyrocalcitonin. Proc. nat. Acad. Sci. (Wash.), 56, 1138.

TASHJian, A.H., JR \& Voelkel, E.F. (1967) Decreased $\vec{I}$ thyrocalcitonin in thyroid glands from patients with is hyperparathyroidism. J. clin. Endocr. 27, 1353.

TAUBER, S.D. (1967) The ultimobranchial origin of thyro- 음 calcitonin. Proc. nat. Acad. Sci. (Wash.), 58, 1684.

Thompson, B., IsLer, H. \& SARKAR, S.K. (1962) Effect of $\checkmark$ hypophysectomy and growth hormone on the light cells of the thyroid gland. Endocrinology, 70, 786.

WALKER, D.G. (1966) Counteraction to parathyroid therapy in osteopetrotic mice as revealed in the plasma calcium level and ability to incorporate $3 \mathrm{H}$-proline into bones. Endocrinology, 79, 836.

Wallach, S., Chausmer, A., Mittleman, R. \& Dimich, A. (1967) In vivo inhibition of bone resorption by thyrocalcitonin. Endocrinology, 80, 61.

Wells, H. \& Lloyd, W. (1968) Possible involvement of cyclic AMP in the actions of thyrocalcitonin and parathyroid hormone. In: Parathyroid Hormone and Thyrocalcitonin (Calcitonin) (Ed. by R. V. Talmage and L. F. Bélanger). Excerpta Medica, Amsterdam. (In press).

Williams, G.A., Hargis, G.K., Galloway, W.B. \& Henderson, W.J. (1966) Evidence for thyrocalcitonin in man. Proc. Soc. exp. Biol. (N. Y.), 122, 1273.

WOODHOUSE, N.J.Y. \& BARNES, N.D. (1968) The response of athyroidal patients to calcium infusion, evidence for an action of thyrocalcitonin. In: Calcitonin: Symposium on Thyrocalcitonin and the C Cells (Ed. by S. Taylor), p. 361. Heinemann Medical, London. 